\title{
China and the "Singapore Model": Perspectives from Mid-level Cadres and Implications for Transnational Knowledge Transfer
}

Hong Liu ${ }^{*}$ and Ting-Yan Wang ${ }^{\dagger}$

\begin{abstract}
Over the past three decades, China has shown tremendous interest in the "Singapore model" through its sending of tens of thousands of cadres to Singapore for executive training and graduate education. Although this phenomenon has been studied, no attention has been drawn to the perspectives of those mid-level cadres who took part in the training and what those perspectives might imply. Utilizing a unique dataset of over 1,350 mid-level cadres graduating from the "Mayors' Class" in Singapore from 1995 to 2016 and follow-up surveys and interviews, this article intends to fill this gap. We found that the most appealing characteristics of the "Singapore model" for these mid-level officials lay in practical governance lessons and their potential transferability rather than in ideologies. This finding challenges conventional wisdom that the most plausible rationale of China's learning from Singapore is political. We also examine Xi Jinping's view of Singapore and its relevance to China's latest national agendas in building a "learning nation" and strengthening the CCP's resilience through anticorruption and intra-party regeneration. The conclusion places the ChinaSingapore case within the context of the changing trend of transnational knowledge transfer in the non-Western world.
\end{abstract}

Keywords: China; Singapore model; mid-level cadres; learning nation; transnational knowledge transfer

Singapore, as a small city-state, has attracted a disproportionate amount of interest from China since the latter started its process of economic reform and opening up. Following Deng Xiaoping's visit to Singapore in late 1978, hundreds

* School of Social Sciences and the Nanyang Centre for Public Administration, Nanyang Technological University, Singapore. Email: liuhong@ntu.edu.sg.

$\dagger$ Nanyang Centre for Public Administration, Nanyang Technological University, Singapore. Email: tywang@ntu.edu.sg (corresponding author). 
of high-ranking delegations were dispatched to visit it. The "Singapore fever" was intensified by Deng's Southern Tour in 1992, during which he made the widely cited statement that "Singapore's social order is rather good. Its leaders exercise strict management. We should learn from their experience, and we should do a

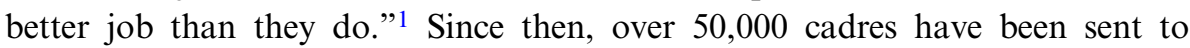
Singapore on almost a monthly basis to study every aspect of the so-called "Singapore model."2 It has been suggested that Singapore constitutes only the second role model for China after the Soviet Union, and has been the only country called on by the Chinese Communist Party (CCP) leaders to learn from since the late 1970 s. $^{3}$ In a recent Asia Barometer survey, the top two learning models in Chinese ordinary people's eyes are the US and Singapore. ${ }^{4}$

China's needs have met proactive response from the supply side. Local institutes in Singapore exemplified by Nanyang Technological University (NTU), National University of Singapore, and the Civil Service College have been extensively involved in this knowledge transfer process by providing customized education programmes for CCP cadres, covering subjects ranging from economic development, public administration, housing and grassroots politics to urban planning and anti-corruption. As the then Vice President Xi Jinping highlighted in 2011, "Tens of thousands of Chinese officials at various ranks have been to Singapore for visiting and studying," and "this has played an important role in promoting bilateral relations and China's construction for modernization."5 $\mathrm{Li}$ Yuanchao, the then Minister of the Department of Organization of the CCP Central Committee which is in charge of nurturing cadres among the 80 million CCP members, spoke favourably about Singapore in April 2010: "Out of all the destinations where we send our leading officials to receive training, Singapore is our top choice because Singapore is the most sincere in helping China develop, due to our longstanding warm relationship."6

Among various education programmes, the so-called Chinese "Mayors' Class" administered by NTU attracted the most media and academic attention for the following reasons: 1) its long history, which could be traced back to 1992, the first such programme in Singapore (and beyond); 2) its large quantity of

1 Vogel 2012, 589.

2 The number $(50,000)$ is drawn from Singapore Deputy Minister Teo Chee Hian: Teo Chee Hean. 2015. "Forging consensus with our people, building national unity." Opening speech at the 15th ChinaSingapore Forum on Leadership, 10 April 2015, http://www.psd.gov.sg/press-room/speeches/openingaddress-by-deputy-prime-minister-teo-chee-hean-at-the-fifth-singapore-china-forum-on-leadership. Accessed 29 March 2016.

3 Lim and Horesh 2016; Zhao, Lingmin. 2015. "Xinjiapo shi weiyi bei zhongguo lingdaoren dianming xuexi de guojia, ping shenme?" (Why did Singapore constitute the only country explicitly called on by Chinese leaders to learn from?), Xinjiapo yan, 8 September, http://toutiao.com/i6191 993370699055617/. Accessed 8 September 2015.

4 Chu, Huang and Lu 2015.

5 China Embassy. 2011. "Xijinping huijian xinjiapo qian zongli liguangyao" (Xi Jinping met with the former Prime Minister of Singapore, Lee Kuan Yew), 23 May, http://www.chinaembassy.org.sg/chn/xwdt/ t824712.htm. Accessed 12 April 2016.

6 Cited in Koh, Tommy. 2017. "Singapore's friendship with China," The Straits Times, 2 May. Koh is ambassador-at large of the Singapore Ministry of Foreign Affairs. 
graduates, with about 1,350 alumni by 2016; and 3) its widespread influences. Over 60 per cent of the students were (vice) mayors or cadres of equivalent or higher ranks, ${ }^{7}$ which was why the programme obtained its reputation as the "Mayors' Class." It comprises two master-degree programmes: Master of Science in Managerial Economics (MME) and Master of Public Administration (MPA). It emerged initially as a cooperative education project between the Organization Department of the CCP Central Committee and Singapore Ministry of Foreign Affairs, under the "Agreement on Delegating Senior Chinese Cadres to Study and Exchange in Singapore" signed by the Ministries of Foreign Affairs of the two countries in 2001, 2005, 2009 and 2014. ${ }^{8}$

In recent years, and especially since the 18th CCP Congress in 2012 when Xi became the CCP Secretary-General, China's modelling of Singapore has gained growing attention, many making reference to the "Mayors' Class." Some studies employed the "Mayors' Class" case as vital evidence of China's obsession with the "Singapore model," arguing an ideological alliance between China and Singapore based upon "soft-authoritarianism," or attributing the close learning relationship to Singapore's effective ruling style exemplified by Lee Kuan Yew. ${ }^{10}$ While useful, the existing studies relied on secondary aggregate data, published reports or commentaries, paying no attention to the structure of the education programmes and perspectives of those cadres trained in Singapore, thus weakening (and sometimes invalidating) their arguments.

This article explores China's knowledge of the "Singapore model" from the perceptions of mid-level cadres educated in the "Mayors" Class," placing particular focus on the most attractive elements - through the participants' eyes - of the "Singapore model" and its transferability to China. We take issue with Kean Fan Lim and Niv Horesh, who conclude that the most plausible rationale of Chinese policymakers in proclaiming the importance of learning from Singapore is political. ${ }^{11} \mathrm{We}$ argue that the motivations behind the CCP's continuous interest in Singapore are multifaceted; from the perspectives of those mid-level cadres, the most appealing characteristics of the "Singapore model" lie in practical governance lessons including meritocracy, clean and efficient governance, and rule of law, rather than in ideologies such as authoritarianism and one-party dominance.

This article employs a mixed methodology utilizing quantitative and qualitative data. We collected hitherto untapped graduate data from the "Mayors' Class," including the students' biographical information submitted upon their entrance to the programme and their profiles, updated in 2016. We also conducted an online questionnaire survey and face-to-face interviews pertaining to

7 See the third section of this article for details.

8 Sun and Lancaster 2013. Ministry of Foreign Affairs of PRC. 2015. "Zhongguo tong xinjiapo de guanxi" (Sino-Singapore relations), July, http://www.fmprc.gov.cn/web/gjhdq_676201/gj_676203/yz 676205/1206_677076/sbgx_677080/. Accessed 13 August 2016.

9 Ortmann and Thompson 2014.

10 Ho 2015.

11 Lim and Horesh 2016. 
graduates' current working status, their perceptions of the "Singapore model" and its applicability and effectiveness in China, in addition to other openended questions. The survey was carried out from September to December 2015 through emails, yielding 193 respondents out of 1,160 graduates surveyed (response rate: 17 per cent). ${ }^{12}$ With a view to understanding the larger frameworks within which the "Singapore model" is situated, we examined writings by the "Mayors' Class" graduates and Xi's comments on Singapore. Although the "Mayor's Class" was established prior to Xi's assuming of power, his standpoint on this issue is of importance in determining whether the experience learnt by the mid-level cadres would remain relevant, especially at a time when $\mathrm{Xi}$ is completing his first term and observers are convinced that Singapore will continue to inspire China under his leadership. ${ }^{13}$ Other data include official party publications and social media platforms such as the Study Times (Xuexi shibao 学习时报), an organ of the Central Party School (CPS) of which Xi was President from 2007 to 2012, and the Xuexi Group (xuexi xiaozu 学习小组), ${ }^{14}$ a social media platform formally associated with the People's Daily.

This article is organized in three sections. After reviewing the "Singapore model" and China's interest in it, we examine in detail the findings on the "Mayors' Class" in order to reveal the most appealing aspects of the "Singapore model" and its transferability. The third section analyses Xi's views of Singapore in the context of a transforming China. The article concludes with the implications of the case of the "Mayors' Class" for the intra-Asia transnational knowledge transfer.

\section{The "Singapore Model" and Its Attraction to China}

Within a relatively short span of 52 years following independence in 1965, Singapore has elevated itself to the status of a developed economy enjoying political and social stability, with GDP per capita jumping from US\$500 in 1965 to US $\$ 56,000$ in $2014 .{ }^{15}$ Singapore's success has often been attributed to the "Singapore model," a term first coined in the 1990s. ${ }^{16}$ Although widely applied, it is a controversial concept. Two main camps held opposite views about its virtues and vices: for those admirers of Singapore's economic miracle and stability, the "Singapore model" was characterized in terms of growth, meritocracy, morally upright government, high standard of livelihood, and social harmony

12 Comparing the survey dataset with the graduate dataset based on key variables including age, gender, provinces, administrative ranks, working sectors, etc., the former was found to be representative of the latter.

13 Horesh and Paris 2017.

14 Translated by the authors as there is no official translation for this group. Xuexi could also mean to "study Xi" in Chinese.

15 "World Bank national accounts data", http://data.worldbank.org/indicator/NY.GDP.PCAP.CD?end= 2015\&locations=SG\&start=1968\&year_high_desc=true. Accessed 3 November 2016.

16 Ortmann and Thompson 2014. 
and order. ${ }^{17}$ The critics, in contrast, pointed out the "dark side" of the "Singapore model" in terms of its authoritarianism and elitism. ${ }^{18} \mathrm{We}$ argue that the "Singapore model" has three key dimensions: 1) a strong state (under the longstanding one-party dominance), facilitating efficient governance; 2) dynamic economic development strategies; and 3) effective policy implementation.

The simultaneous debates about the so-called "China model" provide clues behind China's fascination with Singapore. Discussion about the "China model" gained popularity after 2004, when Joshua Cooper Ramo first coined the term the "Beijing Consensus" which aroused the first wave of "China model" debate. ${ }^{19}$ Some featured China as a developmental state ${ }^{20}$ similar to other East Asian countries including Singapore, while other proponents of the "China model," such as Pan Wei, Wang Hui, Martin Jacques and Daniel Bell, highlighted the uniqueness, appropriateness, legitimacy and advantages of the "China model," in contrast to the Western model of liberal democracy. ${ }^{21}$ Bell, for example, argues that the "China model" is a "Chinese-style vertical democratic meritocracy" that includes "democracy at the bottom, experimentation in the middle, and meritocracy at the top." 22

Almost all of these arguments rest upon an assumption that China is historically and culturally divergent from the West, which is remarkably similar to Lee Kuan Yew's defence of Singapore in his discrediting of Western-style liberal democracy. Meritocracy, deemed an essential element of the "China model," 23 is also at the heart of the "Singapore model." Scholars such as Xiao Gongqin described the "China model" as "new authoritarianism," another significant resemblance to the "Singapore model." 24 Singapore has been first labelled by Francis Fukuyama in 1992 as a "soft authoritarian" country, characterized by a combination of market-oriented liberal economy and paternalistic authoritarian polity. ${ }^{25}$ Based on this concept, Danny Roy found a rhetorical alliance between Singapore and China, driving the latter to seek development lessons from the former. $\mathrm{He}$ contended that soft authoritarianism is influenced by Confucian values (sometimes expressed as "Asian values'), emphasizing education, industriousness, order, filial piety, and selflessness. ${ }^{26}$ In a similar vein, Stephan Ortmann and Mark Thompson argued that soft authoritarianism is the major reason behind China's obsession with Singapore.”27

17 Quah 1998; Sonoda 2014; Ho 2015.

18 Barr 2014; Rajah 2012.

19 Ramo 2004; Zhao 2017.

20 Tang 2016.

21 See, Wang 2011; Pan 2010; Jacques 2010; Bell 2015.

22 Bell 2015, 180.

23 Pan 2010; Bell 2015.

24 Xiao 2014.

25 Fukuyama 1992; Roy 1994.

26 Roy 1994.

27 Ortmann 2012; Ortmann and Thompson 2014. 
The existing literature attributes three dimensions behind Singapore's attraction to China. First, both countries share a similar ideological stance in resisting Western-style liberal democracy, and Singapore is one of the few countries in the world that has successfully combined stable one-party dominance and sustained economic growth, which is of particular appeal to the CCP. ${ }^{28}$ Second, Singapore's efficient, effective and incorruptible governance attracted global attention, and China could draw practical lessons from this to strengthen its governance capacity and legitimacy. Third, the majority (74 per cent) of Singapore's population are ethnic Chinese who share the Confucian cultural roots.

Since the early 1990s, Chinese intellectuals started examining the secrets and transferability of the "Singapore miracle," 29 exemplified by growing numbers of publications. A 2006 survey based on the China National Knowledge Infrastructure (CNKI) showed that from 1994 to 2004, 740 articles on Singapore were published in China's Southeast Asian studies journals, far outnumbering those on other (bigger) countries in the region such as Malaysia $(n=198)$ and Indonesia $(n=174)$. The survey attributed the disproportional amount of attention to the Chinese elite's aspiration to model itself on Singapore. ${ }^{30}$

As CNKI is a comprehensive database archiving all formally published articles and graduate theses in China since 1915, we extended the above survey on the same platform but refined the search in a more rigorous manner by excluding irrelevant subjects and extending the timeframe to the end of 2016. Keyword searches on Singapore, Lion City, PAP, and Lee Kuan Yew generated over 45,300 academic articles between 1993 and 2016. The sheer volume of writings is extraordinarily large considering the city-state's tiny size. A more focused search on the "Singapore model" yielded 200 academic publications, with an average of 8.3 pieces per year. Figure 1 portrays an overall rising trend of publications on the "Singapore model" over the past 24 years, signalling a widespread interest in the "Singapore model."

Chinese perceptions of Singapore have been shaped by diplomacy. The decline of writings on Singapore in 2016 (11 in comparison with 36 in 2015, still higher than the average 8.3) might be partly due to diplomatic tensions between the two countries over the South China Sea issue and Singapore's military ties with Taiwan, which aroused a wave of hostility in China (especially netizens) towards Singapore. Nevertheless, the tensions only generated short-term and limited negative impact on China-Singapore relations. Singapore's merchandise exports

28 To be sure, Singapore is not the only country under one-party dominance in Asia which has successfully overcome the middle-income trap; Japan's Liberal Democratic Party (LDP) is comparable to the PAP in this aspect, given that since 1955 the former only briefly lost its dominance in parliament from 2009 to 2012. Both countries were credited with economic success and political stability. However, China would not publicly advocate Japan as a learning model because of the painful memory of Japanese invasion during World War II.

29 Sun 2002.

30 Tang and Zhang 2006. 


\section{Figure 1: Publications on the "Singapore model" in China from 1993 to 2016}

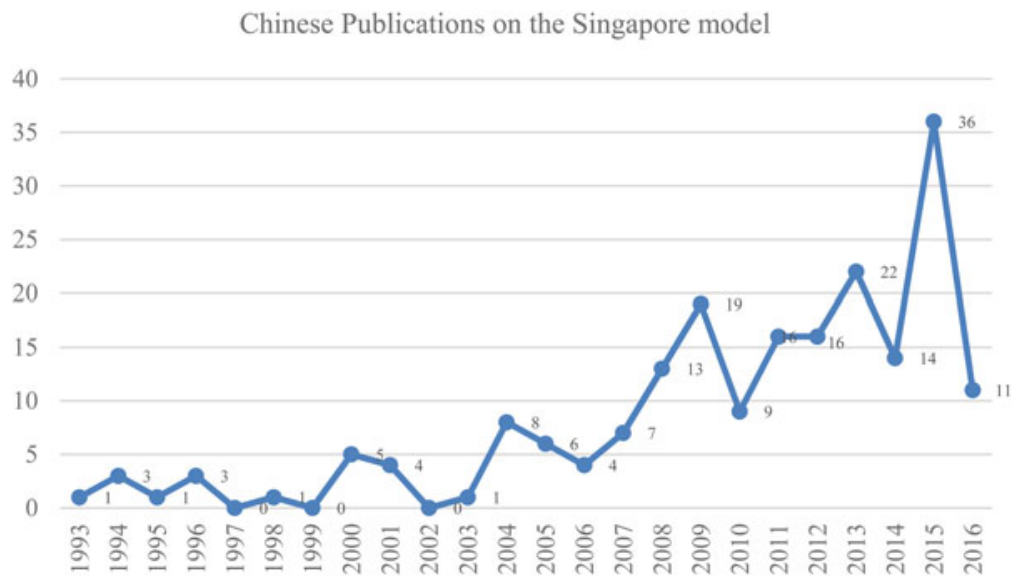

Source:

Computed by the authors based on data from CNKI.

to China have sustained a steady increase since the dispute ${ }^{31}$ and Singapore remained the top investing country in China in 2016. ${ }^{32}$ Even at the height of heated debates over the South China Sea, the People's Daily still considered Singapore as a “Master Teacher (jiaoshi ye 教师爷)" for domestic socioeconomic developments in China, which should still "humbly take heed of suggestions and criticisms from outside including Singapore." Moreover, the "all-weather friendship" between China and Singapore resurfaced in the official discourse of both countries. At the 13th Joint Council for Bilateral Cooperation (JCBC) held in Beijing in February 2017, leaders of both governments highlighted that Sino-Singapore ties have grown from strength to strength. Deputy Prime Minister Teo Chee Hean pledged Singapore's strong support for the Belt and Road Initiative, which is Xi's signature foreign policy. Prime Minister Lee Hsien Loong praised Xi Jinping's endeavour in advocating globalization and free trade, welcoming China's growing engagement with the region as Singapore has a very broad and substantial relationship with China. ${ }^{33}$

China's passion in learning from Singapore (and a few selective countries) is partially rooted in the CCP's championing of building a "learning nation." After 1949, the CCP adopted the "Leaning toward One Side" foreign policy and reconfigured almost every sector of the new country along the Soviet

31 Department of Statistics, Singapore. http://www.tablebuilder.singstat.gov.sg/publicfacing/createData Table. action?refId=4715. Accessed 28 August 2017.

32 Ministry of Commerce, PRC. http://www.mofcom.gov.cn/article/tongjiziliao/v/201702/20170202509836. shtml. Accessed 28 August 2017.

33 "Dialogue with PM Lee Hsien Loong at the EDB Society's Pioneering the Future Series Forum." 20 February 2017, http://www.pmo.gov.sg/newsroom/excerpts-dialogue-pm-lee-hsien-loong-edb-societyspioneering-future-series-forum. Accessed 16 March 2017. 
model. As Mao Zedong put it, "[W]e need to launch a nationwide upsurge of learning from the Soviet Union on how to build our country." 34 Jiang Zeming advocated constructing a "learning party" and considered learning as a vital way to survive in an open and changing world, to combat corruption, and for modernization to materialize. ${ }^{35} \mathrm{Hu}$ Jintao institutionalized this notion by creating a "learning system," extending from collective study by the Politburo members down to study sessions at every level of the Party. ${ }^{36}$ The national network of Party Schools serves as the key institution in nurturing mid-career Party cadres, military officers and selected businessmen. ${ }^{37}$ There are presently 2,753 Party schools at central, provincial and local levels in China, ${ }^{38}$ and the CCP's systemic training of political elites has been considered a major reason in explaining its resilience and capacity to withstand economic reform and social transformation. ${ }^{39}$ After the 1990s, to confront huge challenges of economic reform, socio-political pressures and globalization, China embarked on new and substantial rounds of learning from developed countries. It is against this background that Singapore has emerged as one of the key learning reference points. The CCP leaders, however, do not intend to "become" another country through learning, and firmly believe that learning should be based on China's own circumstances and serve China's practical needs. As Xi emphasized in 2015: "We must learn from the fine achievements of other countries in the development of the rule of law. However, learning from others does not amount to simply copying them. Under no circumstance can we engage in 'all-out Westernization', 'complete transplant' of the systems of others, or copy, from other countries indiscriminately." 40

\section{The "Mayors' Class" and Mid-level Cadres' Perspectives of the "Singapore Model"}

Having established the macro-political environments within which Singapore was situated in post-reform China, we now turn to the meso level, namely, those officials who had personal and extensive experience of Singapore. The "Mayors' Class" is a one-year, full-time residential programme conducted in Chinese, requiring the completion of at least ten courses (three core courses and seven electives ${ }^{41}$ ) and requiring a thesis in order to obtain a master's degree. Some

34 "Guanche Mao zhuxi de weida haozhao" (To carry out the great call of Chairman Mao), People's Daily, 10 February 1953.

35 Jiang 2006, Volume I, 99, Volume III, 185.

36 Tsai and Dean 2013.

37 Wibowo and Lye 2006; Shambaugh 2008.

38 Lee 2015

39 Wibowo and Lye 2006; Shambaugh 2008; Lee 2015.

40 Xi 2015.

41 The core courses of the MPA programme include "Introduction to Public Administration, Market and Market Failure, and Public Strategic Administration," and for the MME programme are "Managerial Economics: Theory and Applications, Macro Economics" and "Human Resources Management and Labour Economics." 
graduates wrote monographs based on their study experience in Singapore, and recalled that completing the degree courses was no easy task for middle-aged cadre students, in particular having to face the possibility of exam failure and therefore not being awarded the degree. ${ }^{42}$

The origin of the "Mayors' Class" can be traced back to 1992, soon after the establishment of diplomatic relations between China and Singapore in 1990 and Deng's Southern Tour in Spring 1992. At first, there were only one or two shortterm programmes a year, hosted by the Nanyang Business School at NTU; later in 1994, the demand escalated to almost one training programme every month. ${ }^{43}$ In 1998, NTU launched a master-degree programme (MME) specifically for Chinese cadres, followed in 2005 by the launch of the MPA. ${ }^{44}$

A key feature of the "Mayors' Class" is extensive incorporation of the Singaporean experience in its curriculum. There are Singapore-specific courses such as Singapore Public Administration, Singapore's Green Policies, The Social Management System of Singapore, Rule of Law and the Legal System in Singapore, etc. Former ministers, parliament members, and senior civil servants served as adjunct professors lecturing on a regular basis. They include Yeo Ning Hong (former Minister for Communications and Information), Yeo Cheow Tong (former Minister for Health, Trade and Industry), and Mah Bow Tan (former Minister for Communications, Environment, and National Development), to name just a few. With rich experience in the governance of Singapore as well as knowledge of China, they were able to structurally link the Singaporean lessons with China's circumstances. For example, Chan Soo Sen, former Minister of State for the Prime Minister's Office, Education, and for Trade and Industry, served as the first CEO of the China-Singapore Suzhou Industrial Park Development Co. between 1994 and 1996. During and after the lectures, the cadre-students had heated discussions with the Singaporean politicians and exchanged ideas on governance issues. Besides the structured lectures, the programme also organized site visits to various government departments, statutory boards, parliament members' meet-the-constituents sessions, the Corrupt Practices Investigation Bureau, Science Park, community-level grassroots organizations etc., thus enabling the students to gain first-hand knowledge of the operation of the Singapore government.

Based on data collected, 1,350 Chinese students had graduated from the "Mayors' Class" by 2016. At the time of admission, 72 per cent were working in the government sector while most of the rest were from state-owned enterprises or public institutions such as Women's Federations and universities. Our survey data show that 86.4 per cent of the cadre-students received recommendations

42 Ma 2004; Wang 2008.

43 Cham 2014.

44 In 2009, NTU founded the Nanyang Centre for Public Administration (NCPA), taking overall charge of the "Mayors' Class" and other short-term executive education programmes for officials from China and other Asian countries. By 2016, more than 15,000 officials have attended these short-term training programmes. 
from their work units in order to study at NTU, 60.2 per cent were selected through a competitive process, and the majority, 86.4 per cent, were financially supported by their work units.

\section{A demographic analysis of the "Mayors' Class" and its influence in China}

Before exploring the graduates' perspectives of the "Singapore model" and its transferability, we examine the potential influence of the "Mayors' Class" graduates in China. The metrics employed are the cadre-students' geographical distribution, administrative ranks, quality, and career benefits from their education in Singapore.

In terms of geographical distribution, the "Mayors' Class" graduates covered 33 province-level administrative regions in the PRC, almost all of the country. As the pioneer province for sending government leaders to NTU, Hebei tops the list of the "Mayor's Class" by having sent 181 cadres. Beijing and Chongqing follow closely, with 131 and 122 students respectively.

Data show that most of the "Mayors' Class" graduates are mid-level cadres and executive leaders in their respective localities. ${ }^{45}$ Figure 2 compared the cadre-students' administrative ranks at the time of their entrance to NTU from 1995 to 2015, updated in 2016. The proportions of Division-Head, DeputyBureau-Director, and Bureau-Director ranks have increased significantly from 23.6, 19.9 and 3 per cent to 28.2, 31.5 and 8.9 per cent respectively, while the proportion of the relatively lower-level Deputy-Division-Head rank has decreased from 36.3 to 31.5 per cent. A total of 82.8 per cent of the graduates working in the government sector were holding (vice) mayor-level positions when studying at NTU; that proportion increased to 92.5 per cent in 2016. In other words, almost all the "Mayors' Class" graduates working in the government sector are now top executive leaders of their local or functional areas. When a cadre is promoted to a leading executive position such as party secretary or mayor, he/she has the authority in terms of policymaking and policy implementation, which in turn has a direct impact upon that area.

The "Mayor's Class" was dubbed the CCP's "Overseas Party School" by the Voice of America, referring to its special status in China. ${ }^{46}$ There are substantial

45 In China, public officials in leadership positions are ranked in a complex hierarchy from the highest National leader to the lowest Deputy-Section-Head level. In between are Sub-National leader, Provincial-Ministerial level, Sub-Provincial (Ministerial) level, Bureau-Director level, Deputy-BureauDirector level, Division-Head level, Deputy-Division-Head level, and Section-Head level. Mayors are inclusive of the four levels above the section-head level.

46 Tan 2012. "Nanyang ligong peixun zhongguo guanyuan xiaofang xinjiapo moshi" (NTU training Chinese cadres to emulate the "Singapore Model"), Voice of America, 13 December. http://www. voachinese.com/a/singapore-chinese-official-20121213/1563978.html. Accessed 23 March 2015. This report was reprinted by China's official media Xinhuanet.com in 2012. "Meimai baodao nanyang ligong daxue cheng zhonggong haiwai dangxiao" (US media: NTU of Singapore is becoming China's Overseas Party School), 17 December, http://news.xinhuanet.com/world/2012-12/17/c 124105286.htm. Accessed 23 March 2015. Fu Jing, "Overseas training boosts China's development," China Daily, 6 July 2016. 
Figure 2: Changing Administrative Ranks of the Cadre-Students of the "Mayors' Class" (1995-2016)

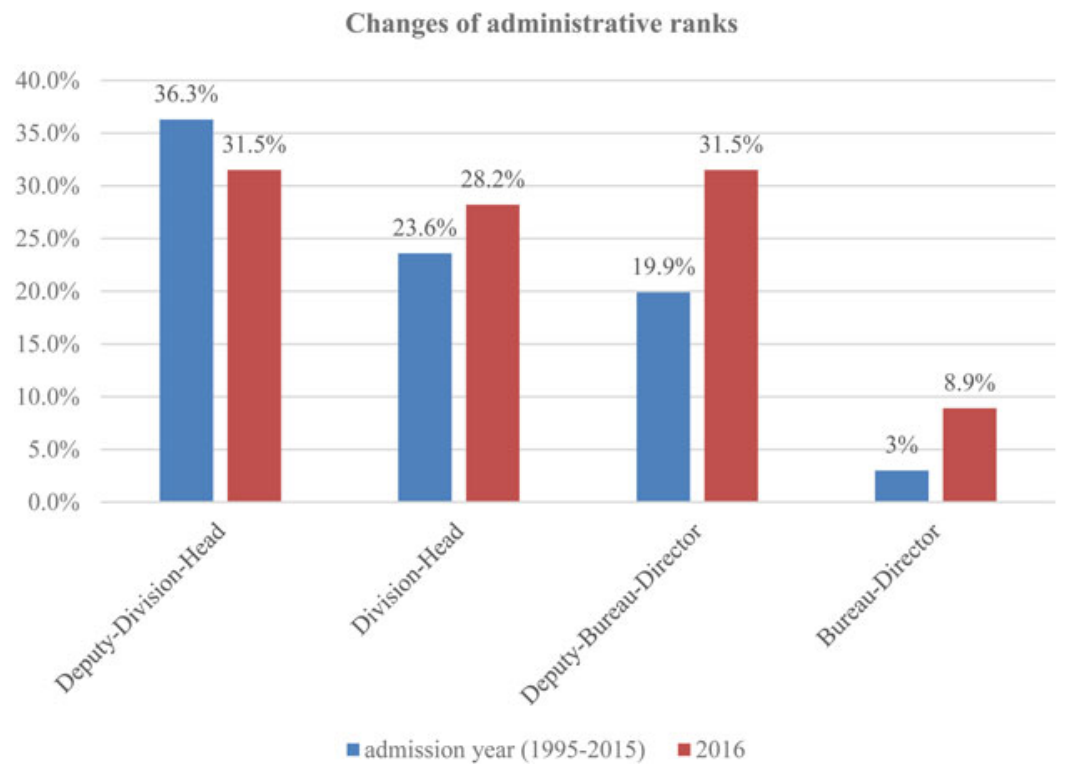

Source:

Calculated by the authors based on graduate data from NTU.

differences between the two, but a key resemblance between them is the high calibre of their participants. China's Party Schools at different levels are tasked to nurture promising cadres who have the potential to be promoted to leadership positions either in party sector or government, namely the Reserve Cadres. To be selected, cadres must fulfill the following requirements: ${ }^{47}$

1) Youth, in line with the party's principle of Youthful Rejuvenation. To be included on the list for provincial/ministerial-level reserve cadres, cadres are normally between 45 and 50 years old; prefectural/bureau-level candidates aged from 40 to 45 ; and county/divisional-level candidates between 35 and 40;

2) Superior leadership capacity based upon substantial work experience;

3) Good educational background, accordant with party's principle of Intellectualization;

4) "Correct" political stand.

Most cadre-students in our data are well qualified to be grouped among Reserve Cadres: more than half are 35 to 45 years old, accounting for 67.5 per

47 Hu 2011; Tsai and Kou 2015. Liu, Yanchuan. 2015. "Xunzhao jiebanren: jiemi "houbei ganbu zhidu"” (Looking for successor: demystify the Reserve Cadre system), CNpolitics.org, 4 June, http://cnpolitics. org/2015/06/ccp-reserve-cadres. Accessed 1 March 2016. 
cent of the total intake; before entering NTU, 81.8 per cent had a Bachelor's degree and 16.5 per cent a Master's degree; the average length of work experience when entering the "Mayors' Class" is 14.4 years, and 52 per cent had accumulated 14 to 21 years of work experience, indicating their potential for taking on greater responsibilities.

A comparison of data collected at the time of admission in various years and the updated data in 2016 shows that most cadre-students' administrative ranks have been enhanced substantially and the promotion is statistically significant. We encoded the level of "National leader" as "1," the "Sub-National leader" as " 2 ," and the other lower levels as numbers in ascending order with an interval of one. A larger value refers to a lower rank while a smaller one to a higher rank.

Figure 2 shows that most cadre-students were concentrated at the levels from Deputy-Bureau-Director (code $=6$ ) to Deputy-Division-Head (code =8) when enrolling in the "Mayors' Class"; later in 2016 their ranks changed upward, with more clustered in the categories of the Bureau-Director level (code $=5$ ), Deputy-Bureau-Director level (code =6), and Division-Head level (code =7). To test whether these changes are statistically meaningful, we conducted a Paired-Samples $T$-test to evaluate its significance. The analysis results in Table 1 show that the average value of students' initial administrative ranks is 7.75, which has decreased to 6.99 with an absolute change of -0.76 in 2016 . This decline is statistically significant with a $p$ value lower than $.001 \quad(T=$ $10.640 ; p=0.000)$. A straightforward way to interpret this finding is that the cadres' average administrative levels were between Division-Head (code $=7$ ) and Deputy-Division-Head (code $=8$ ) when they were studying in Singapore, and in 2016 they had been promoted to the levels between Deputy-BureauDirector level (code $=6$ ) and Division-Head level (code $=7$ ). Although these findings alone cannot confirm a causal relationship between "Mayors' Class" education and the graduates' subsequent promotions, they do demonstrate that these cadres-students are among the most promising middle-level cadres as well as the relevant significance of their Singapore experience.

\section{Mid-level cadres" perspectives of the "Singapore model"}

The survey $(\mathrm{N}=193)$ found that almost all (96.3 per cent) of the respondents agree that Singapore's governance reflects the existence of a "Singapore model." The survey provided a series of options on the core elements of the Singapore model and the respondents were able to select the ones they perceived to be most crucial and most attractive. ${ }^{48}$ Figure 3 presents the supporting rates for the 12 elements of the "Singapore model," which are: 1) one-party dominance, 2) authoritarianism, 3) periodical democratic election, 4) meritocracy, 5)

48 The selection of these 12 core features was not only based on the authors' understanding of the "Singapore model" but also drawn upon comments of experts and practitioners in the field, such as Goh Nguen Wah and Chew Soon Beng who have been long-term lecturers for the Mayors' Class. 
Table 1: Comparison of Students' Administrative Ranks in Admission (Various Years) and in 2016

\section{$M(S D)$}

\section{In admission}

$7.75(1.340)$

Notes:

${ }^{*} p<.05 ;{ }^{* *} p<.01 ;{ }^{* * *} p<.001$. Calculated by the authors based on data from the NTU Office of Alumni Affairs.

\section{$T$-test}

\section{In 2016}

$6.99(1.196)$ $\mathbf{t}$ (df)

$10.640 * * *(539)$ $p$

0.000

clean and efficient government, 6) rule of law, 7) grassroots social management, 8) racial and religious harmony, 9) economic success, 10) the Temasek model, ${ }^{49}$ 11) public housing, and 12) Central Provident Fund (CPF). ${ }^{50}$ The 12 elements are further categorized in analysis into four major dimensions including polity/ideology (one-party dominance, authoritarianism, and periodical democratic election), governance (meritocracy, clean and efficient government, rule of law, grassroots social management, and racial and religious harmony), economics (economic success and the Temasek model), and social services (public housing and $\mathrm{CPF}$ ). The supporting rates for each dimension are shown in Figure 4.

Figures 3 and 4 show interesting findings: only 28.6, 45, and 31.7 per cent of the respondents consider, respectively, "one-party dominance," "authoritarianism," and "periodical democratic election" to be key components of the "Singapore model." The average supporting rate for the elements listed under the category of "polity/ideology" is modest ( 35.1 per cent). These findings are in a stark contrast to the established conclusion that the most alluring features of the "Singapore model" to China lie in their ideological resemblance, such as "soft authoritarianism" and long-term one-party dominance. While there is no denying that authoritarian politics has been a driving force behind China's Singapore fever, our empirical analyses provide an alternative lens by which to re-examine the reasons underpinning China's continuous obsession with the "Singapore model" from the perspectives of mid-level cadres educated in Singapore, thus challenging the sweeping statement that the most important motivation for China's interest in Singapore is the study of ideological politics, for the purpose of maintaining the CCP's one-party and authoritarian rule.

The cadre-students gave more weight to practical governance lessons rather than Singapore's polity. The rate of support for the "governance" dimension is 75.4 per cent, highest among all the dimensions. The indicators contributing the largest weight are "meritocracy" ( 88.9 per cent), "clean and efficient governance" (87.3 per cent), and "rule of law" (81 per cent). Singapore's economic

49 The Temasek Holdings is a government-controlled investment vehicle with full operational autonomy competing in a free market globally. See for details in http://www.temasek.com.sg/.

$50 \mathrm{CPF}$ is a compulsory comprehensive savings plan for working Singaporeans and permanent residents primarily to fund their retirement, healthcare and housing needs. Information drawn from CPF website at https://www.cpf.gov.sg/Members/AboutUs/about-us-info/cpf-overview. Accessed 7 October 2016. 


\section{Figure 3: Respondents' Supporting Rates of the Proposed Elements}

\section{Supporting rates of the elements}

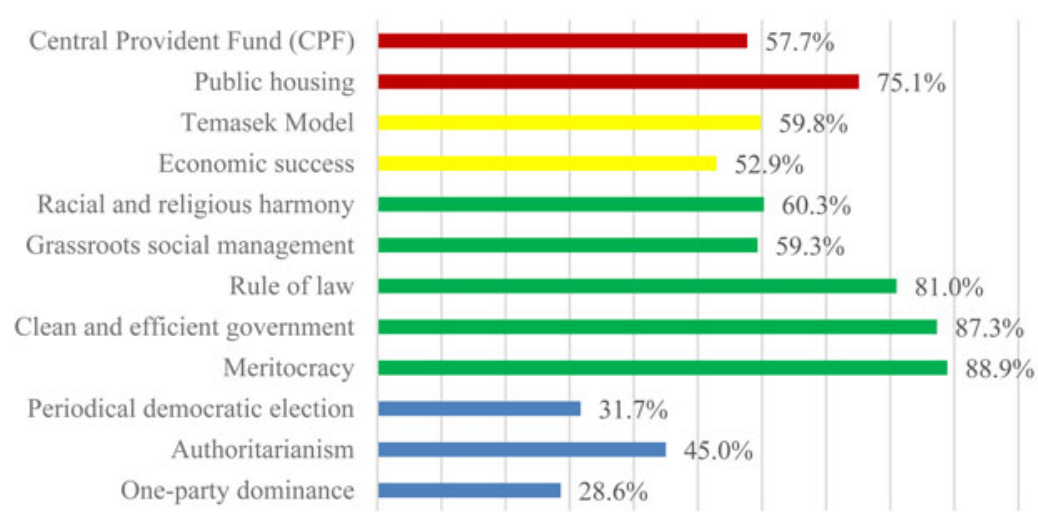

$0.0 \% 10.0 \% 20.0 \% 30.0 \% 40.0 \% 50.0 \% 60.0 \% 70.0 \% 80.0 \% 90.0 \% 100.0 \%$

Source:

Calculated by the authors based on the survey data.

Figure 4: Respondents' Supporting Rates of the Four Dimensions

Supporting rates of the dimensions

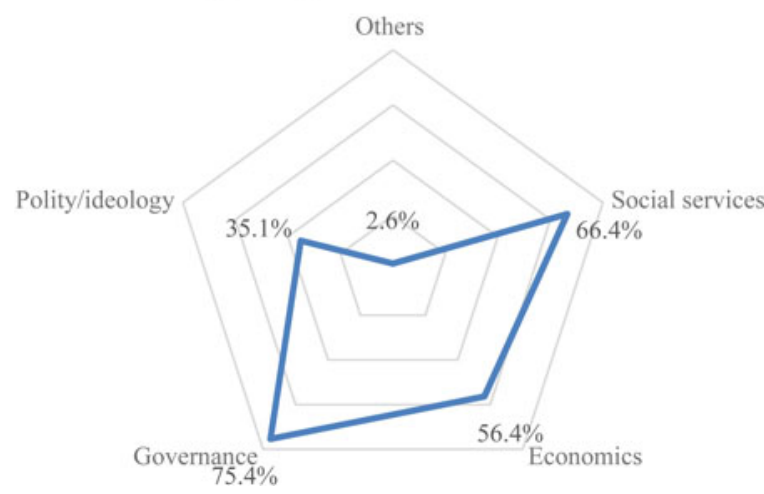

Source:

Calculated by the authors based on the survey data.

success seems to be less appealing to these mid-level cadres. Items such as "economic success" and the "Temasek model" did not receive many votes. "Public housing" was viewed favourably, with an approval rate of 75.1 per cent. These findings confirm the shift in the development focus under $\mathrm{Xi}$, namely, less emphasis on GDP growth but more on better life for all the people under the framework of the "Chinese Dream."

Controversy exists as to whether the Singaporean experience could be transplanted to China. Many scholars and policymakers are sceptical about the 
transferability of the "Singapore model" to other countries, especially to the populous and geographically vast China, while others argue that its good practices could be adapted to the context of China or act as an inspiration to stimulate contextual policy innovations. Our survey showed that 72.5 per cent of the respondents believed that the Singaporean experience could be gradually and selectively applied in China. While fully aware of the significant differences between the two countries, they remain convinced that Singapore's operational practices and principles (e.g., "Homes for All," and rule of law) could operate in China as China fosters a modernized civil society. Below is a summary of the main responses to the open-ended question as to whether the "Singapore model" is transferable to China: ${ }^{51}$

- Part of the Singaporean experience could be transferred to China step by step, after making necessary adjustments according to China's circumstances;

- Singapore is a very successful model of modern governance and worthwhile making reference to, especially nowadays when China faces new challenges of modernizing its governance capability and government system, as pledged by President $\mathrm{Xi}$;

- The party-building of the PAP and the government's clean image is worthwhile studying;

- Rule of law, clean government, and racial harmony policies are transferable to China;

- The "Mayor's Class" played an important role in transferring Singaporean governance lessons to China. Public housing, CPF, anti-corruption policies, and the "Temasek model" all have been partially or fully transplanted into China and proved to be successful;

- It is difficult to transfer the "Singapore model" to China because a huge gap exists between the two countries in terms of national quality, education level, governance efficiency and capacity, maturity of legislation etc.

There was a widespread expectation that after graduation from the programme in Singapore, the cadre-students would be able to apply what they had learned when back in China. One middle-ranking cadre from Shandong who graduated in 1999 recalled that after reading his graduation report the then Vice Governor commented that he looked forward to the implementation of some of the measures. ${ }^{52}$ A city party secretary shared his view that his studies on managerial economics courses had enabled him to lead, confidently and competently, the discussions and formulations of economic policies. ${ }^{53}$ Another official (at the level of Deputy-Director-General) told us that he returned in 2007 to Qinghai 
province "with enthusiasms and the intention to apply" what he had learned in Singapore. ${ }^{54}$

In short, the perspectives and experiences of the cadre-students differ from the conventional wisdom, which held that ideological expediency plays a key role in China's learning from Singapore. Instead, these students found themselves more attracted to the practicability and transferability of the "Singapore model" in its social, economic and political governance. ${ }^{55}$ Their intensive immersion in courses (many of which were taught by practitioners and senior civil servants) pertaining to Singapore's management of success, as well as field visits to various public agencies, provided them with a unique perspective from which to understand developments in Singapore. This has been reinforced by their extensive experiences in China and questions they attempted to address prior to embarking on their studies.

\section{Xi Jinping's View of the "Singapore Model"}

We have demonstrated that the majority of the cadre-students enrolled in the "Mayors' Class" have made significant progress in their political careers through steady promotion following graduation. Their perceptions of Singapore and the feasibility of transferring some elements of the "Singapore model" are conditioned by the overall political environments in China, especially Xi Jinping's vision for China's future.

Although Xi Jinping seldom expresses his views on different modes of development and is fully confident of China's own political path, various studies have revealed his interest in the Singapore experience. ${ }^{56}$ Like his predecessors, consistent learning and training of party cadres is one focal point of Xi's views on governance. The great significance of the continuous training of CCP's officials was highlighted in his speech to the national Organization Department meeting in 2013, entitled "Train and select good officials," pinpointing "learning is the process toward progress." ${ }^{57}$ After Xi's rise to China's top position, he expressed positive views about Lee Kuan Yew and Singapore. When Lee's book Lee Kuan Yew: The Grand Master's Insights on China, the United States, and the World was released in China in 2014, Xi wrote an endorsement for the book, something that is unprecedented for a top Chinese leader to have done. Disagreeing with Lee's comments in 2010 that it might soon be Singapore's turn to learn from China, $\mathrm{Xi}$ responded by emphasizing that there is still much to learn from Singapore, especially in the area of institutionalization. ${ }^{58}$

54 Interview with a cadre-student, Qinghai, January 2016.

55 Gao and Liu (2017) provides examples of some Chinese cities applying the "Singapore model" to their local governances.

56 Zhang 2013; Ortmann and Thompson 2014; "Xinren 7 changwei jianjie" (A brief introduction to the seven newly appointed standing members), Mingbao, 26 November 2012.

57 Xi 2014, 460-471.

58 Lee $2014,38$. 
The Study Times and the Xuexi Group indirectly help to reveal Xi's views of Singapore. The former is an influential periodical published triweekly by CPS, aimed primarily at lecturers and administrators in party schools and other parts of the CCP's propaganda system. ${ }^{59}$ Its main role is to initiate policyoriented discussions on crucial issues to guide thinking among Party members. From 2008 to 2016, the Study Times published about sixty essays detailing the Singaporean experience, covering a wide variety of areas such as the PAP and Singapore's political system, social management, "the Temasek model," public housing, and with topics like anti-corruption and party-building receiving the highest level of attention in terms of occurrence frequency. This is in tandem with the major tasks that $\mathrm{Xi}$ and the CCP leadership have carried out since 2012, with the intention of eradicating rampant corruption and strengthening the CCP's governance capability.

Three peak periods of publications on Singapore occurred in 2008 when $\mathrm{Xi}$ took the post of CPS Presidency, in 2012 when $\mathrm{Xi}$ assumed the role of the Secretary-General of the Party Central Committee, and in 2014 and 2015 when the "deepening reform in an all-round way" was got underway under Xi's leadership. This is perhaps not a coincidence. Within Xi's first two months as the CPS President, the Study Times published five essays on Singapore, leading to the reemergence of a mini-"Singapore fever" during the 18th Party Congress, with eight essays about Singapore being published. Discussions about Singapore were further intensified in 2014 and 2015, with between ten and thirteen essays on the "Singapore model" released each year respectively. Table 2 shows numbers of essays on Singapore published in the Study Times from 2008 to 2016.

The Xuexi Group is a social media platform with a large number of followers disseminating news and exclusive information about Xi. Since its first essay titled "Understanding Xi's Governance Strategy through 40 Key Words" was released in February 2014, it has received enormous attention from mass media and public officials. Over half of its followers in China are reportedly working in the public sector. ${ }^{60}$ It has become a "must-read" for those interested in Chinese politics or seeking to survive in Chinese bureaucracy. ${ }^{61}$

In March 2015, when Lee Kuan Yew was critically ill and then passed away, the Xuexi Group extensively discussed close connections between Xi, Lee and the "Singapore model." Six essays were released between the 18th and 26th March, focusing on Lee's life, his personal ties with $\mathrm{Xi}$ and their similarities, and Xi's thoughts on the "Singapore model." An essay entitled "Xi, Lee and the "Singapore model"" attracted wide attention both domestically and overseas. Written by Guang Zhao (广昭, a pseudonym meaning “to widely proclaim”), it claimed that there is sound evidence showing that $\mathrm{Xi}$ is inspired by the

59 Pieke 2009, 100 .

60 "Naxie ren guanzhu xuexi xiaozu?" (Who are following the Xuexi Group?), http://chuansong.me/n/ 989525. Accessed 23 March 2015.

61 Xiao 2015. 
Table 2: Number of Essays on Singapore Published in the Study Times (20082016)

\begin{tabular}{lccccccccc}
\hline Year & 2008 & 2009 & 2010 & 2011 & 2012 & 2013 & 2014 & 2015 & 2016 \\
No. of articles & 7 & 2 & 4 & 3 & 8 & 3 & 10 & 13 & 8 \\
Source: & & & & & & & & & \\
Website of the Study Times, http://dzb.studytimes.cn/. & & & & & &
\end{tabular}

"Singapore model" in his endeavour to find a balance between social progress and social control. ${ }^{62}$

Xi's familiarity with the "Singapore model" might be partially attributed to his early work experiences. His formative working experience in Fujian (1985-2002), which is a major ancestral hometown of the Chinese diaspora, might have an impact upon his policy preferences after 2012. For example, China's transnational model of diaspora governance could be traced back to 1995 when $\mathrm{Xi}$, as the Party Secretary of Fuzhou (provincial capital city), published an essay advocating "da qiaowu" (big overseas Chinese work) incorporating both domestic policies and overseas Chinese policies. ${ }^{63} \mathrm{He}$ had visited Singapore six times prior to becoming President and had on numerous occasions interacted with Singaporean officials and businesspeople.

Xi's view of China as a "learning nation" and his favourable impressions of Singapore, therefore, provide a political framework that would ensure the continuing relevance of the Singapore experiences in China and the selective transferability of the "Singapore model," which has been reinforced by the fact that China's investments in Singapore alone amount to about one-third of its total investments in "Belt and Road" countries ${ }^{64}$ as well as the fact that Singapore has been the largest foreign direct investor in China. There are a number of major industrial and innovation parks operating in China, serving as a fertile ground for transnational knowledge transfer. Indeed, it was $\mathrm{Xi}$ who personally announced the third Sino-Singapore Government-to-Government project (Chongqing) during his seventh visit to Singapore in November 2015. ${ }^{65}$

\section{Concluding Remarks}

China's persistent interest in and institutionalized learning from the "Singapore model" has been extensively studied. However, the perspectives of mid-level cadres educated in Singapore - who are key stakeholders in the process - and

62 Guang Zhao. 2015. "Xi Jinping, Li Guangyao yu Xinjiapo moshi” (Xi Jinping, Lee Kuan Yew, and the "Singapore model”), xuexi xiaozu, 23 March, http://chuansong.me/n/1237575. Accessed 24 May 2015.

63 Liu and Van Dongen 2016.

64 Speech by K. Shanmugam, Minister for Home Affairs and Minister for Law, at the Asia Economic Forum on "The One-Belt One-Road Initiative: Impact and Implications" (August 27, 2017). https:/ www.mha.gov.sg/newsroom/speeches/Pages/Asia-Economic-Forum-on-The-One-Belt-One-Road-InitiativeImpact-and-Implications.aspx. Accessed November 11, 2017.

65 Kor 2015. 
the implications of those perspectives have been neglected, partly due to data constraint. This article fills this gap by making use of the graduate data from the "Mayors' Class" programme. This group is important for two main reasons: these graduates are in the forefront of policy implementation on a daily basis and they have first-hand experience not only of China but also the outside world through intensive study in and about Singapore.

We found the cadre-students of the "Mayors' Class" were predominantly interested in the practical aspects of governance and social services, such as "clean and efficient government," "rule of law," and "public housing," demonstrating that their focus in learning from Singapore is pragmatism-oriented rather than ideology-driven. They were generally positive about the selective and gradual transferability of the "Singapore model" within China. Xi's favourable impressions of Singapore and the rapid rise of China demonstrate that the two-way learning relationship is likely to be sustained for the foreseeable future, thus providing a conducive environment for the further growth of the "Mayors' Class" graduates in China's political arenas.

Placing our case in the larger and theoretical context, transnational knowledge transfer, referred to as the process in which the tested policies, administrative arrangements, institutions, best practices or expertise are transferred and applied across countries, ${ }^{66}$ has become increasingly prevalent. Apart from China, other emerging economies in Asia such as Vietnam, Myanmar, Cambodia and the Philippines have also sent high-ranking public officials to Singapore to study good governance and economic management. ${ }^{67}$ It is perhaps in this context that Fan Ning, a prominent public intellectual based in the Chinese Academy of Social Sciences, sees the applicability of the Singapore model beyond China:

By employing a special development path that has never been tried before and accomplishing the nation's industrialization and modernization, the Singapore model has provided successful answers to perplexing problems of our time. This path has certain universal significances and proved to be successful in many Asian countries, thus the Singapore model has entered the systems of experiences (jingyan tixi) of political and social development of the world. ${ }^{68}$

Our case study of Chinese cadre-students provides important implications for fostering sustainable transnational knowledge transfer in the intra-Asian context.

First, our case study has demonstrated a shifting trend in transnational knowledge transfer, in that there have been increasing numbers of exchanges between countries in the broadly defined Global South and an ensuing departure from the one-way flow of knowledge transfer (from North to South) that has dominated development cooperation discourse since World War II. South-South

66 Duan, Nie and Coakes 2010.

67 Ji 2013. Wadhams, Nick. 2015. "China's love of Lee's 'Singapore Model' ran deep for decades," Bloomberg News, 23 March, http://www.bloomberg.com/news/articles/2015-03-23/china-s-love-of-lees-singapore-model-ran-deep-for-decades. Accessed 23 March 2015. Shen, Rujin. 2015. "All roads lead to Singapore: Asians study Lee Kuan Yew's mantra,” Reuters, 23 March, http://www.reuters.com/ article/2015/03/23/us-singapore-lee-asia-idUSKBN0MJ15320150323. Accessed 20 June 2015.

68 Fang 2016. 
knowledge transfer has been growing noticeably, ${ }^{69}$ partly because of geographical proximity and similar political, social and economic challenges. Countries such as Singapore - a former developing country that has transformed itself into a developed nation - and China are paradigmatic examples in this regard.

Second, no knowledge transfer could be undertaken without considering the specific circumstances of the recipient countries. Despite the optimistic perceptions overall of the Singapore model's transferability within China, national leaders, local cadres, and academics are keenly aware of the limitation of the Singapore experience in its applications. The absorption capability comprising the ability to adapt and to innovate is, therefore, crucial in ensuring successful transnational knowledge transfer. ${ }^{70}$ As practitioners on the forefront of policy formulation and implementations, key stakeholders such as the mid-level officials in our case study play an important role in the process of institutionalized knowledge transfer.

Third, transnational knowledge transfer has to be construed as an ongoing and multidirectional process. China has long been a learning nation and good at drawing on any experiences successfully tested by other countries and cultures. Singapore is just one of those, albeit a special and significant one. However, China serves simultaneously at both ends of the knowledge transfer spectrum. It is worthwhile noting that $\mathrm{Xi}$ has recently highlighted the theme of mutual learning (huxue hujian 互学互鉴) between China and Singapore in his meeting with Lee Hsien Loong in July 2017,71 which may herald a new trend in SinoSingapore interactions. With China's rapid economic growth and rising clout in the global arena, the past decade has seen an increasing number of developing countries sending their officials to be trained in China. About ten thousand African officials have been receiving training in China each year since 2000; the number of training courses has risen steadily from the 7,000 places pledged during 2000-2003 to 30,000 places pledged during 2012-2015. ${ }^{72}$ China's role as a provider, apart from being a recipient in the transnational knowledge exchange, is likely to accelerate because China's Belt and Road Initiative is to be expanded substantially in 2017, with US\$4 billion of investment made by the Silk Road Fund and US\$1.7 billion in loans for participating countries provided by the Asian Infrastructure Investment Bank over the past four years. ${ }^{73}$ Indeed, Fukuyama contends that the "One Belt One Road [initiative] represents a striking departure in Chinese policy. For the first time, China is seeking to actively export

69 UN Development Programme. 2013. Human Development Report 2013 - The Rise of the South: Human Progress in a Diverse World, http://www.refworld.org/docid/514850672.html. Accessed 28 August 2017.

70 Duan, Nie and Coakes 2010.

71 "Xi Jinping huijian xinjiapo zongli Li Xianlong" (Xi Jinping met with the Prime Minister of Singapore Lee Hsien Loong), Xinhua, 7 July 2017.

72 Tugendhat and Alemu 2016.

73 "Full text of President Xi's speech at opening of Belt and Road forum", Xinhuanet, 15 May 2017, http:// news.xinhuanet.com/english/2017-05/14/c_136282982.htm. Accessed 17 May 2017. 
its development model to other countries." 74 How China is to make this major transition in the transnational knowledge transfer equation will have a significant impact on our world and is something worthy of closer academic scrutiny.

\section{Acknowledgement}

This study is funded by the Lien Foundation, the Singapore Ministry of Education AcRF Tier 2 Grant (MOE2016-T2-02-87), and a Nanyang Technological University Grant (M4081020). The authors are grateful for the anonymous reviewers of The China Quarterly for their constructive comments. The views in this article are those of the authors who are solely responsible for the interpretations and any remaining errors.

\section{Biographical notes}

Hong Liu is Tan Kah Kee endowed professor of public policy and global affairs, and chair of the School of Social Sciences at Nanyang Technological University in Singapore. He was chair of Chinese studies at the University of Manchester prior to his current appointment. His articles have appeared in, among others, World Politics, The China Quarterly, Journal of Asian Studies, Journal of Contemporary China, Ethnic and Racial Studies, and Current History. He is the co-author (with Gregor Benton) of Dear China: Emigrant Letters and Remittances, 1820-1980 (University of California Press, 2018).

Ting-Yan Wang is postdoctoral fellow of Nanyang Centre for Public Administration at Nanyang Technological University, Singapore. She holds a MA degree in social policy from The Chinese University of Hong Kong and obtained her PhD degree from the University of Hong Kong. She has wide research interests in transnational knowledge transfer, social policy, poverty issues etc. Her articles appeared in prominent journals such as International Journal of Social Welfare.

摘要: 在过去的三十年里, 中国各级政府部门派送了数万名官员到新加坡接 受短期培训或攻读硕士学位课程, 对所谓的 “新加坡模式” 展现了极大的兴 趣。虽然学术界对中国学习新加坡这一现象有所研究，但现有的研究都忽 视这些曾在新加坡受训的中国地方中层官员对 “新加坡模式” 及其在中国 之可行性的看法。通过利用独特的南洋理工大学 “市长班” 毕业生数据库 (1995-2016) 以及后续问卷调查与访谈资料，本文试图填补这一空白。我 们发现；对于这些中层官员来说，“新加坡模式” 中最有吸引力的是具有可 操作性的政府管理经验及其在中国的应用，而非意识形态的吸引力。这一 发现挑战了学术界对中国学习新加坡这一现象的惯常解读, 即; 中国向新 加坡学习的主要考量是出于政治因素。此外，结合中国近年来强调的建设 


\begin{abstract}
“学习型政党”和通过反腐和自我革新提高中国共产党的执政能力, 本文分 析了习近平对于新加坡的看法。结论部分我们将中国与新加坡互学互鉴的 事例放置于非西方世界跨国知识转移这一大背景下进行相关讨论。
\end{abstract}

关键词: 中国; 新加坡模式; 中层官员; 学习型国家; 跨国知识转移

\title{
References
}

Barr, Michael D. 2014. The Ruling Elite of Singapore: Networks of Power and Influence. London : I.B. Tauris.

Bell, Daniel A. 2015. The China Model: Political Meritocracy and the Limits of Democracy. Princeton: Princeton University Press.

Bland, Ben, and Jeevan Vasagar. 2016. "Why Singapore's Taiwan ties anger China," Financial Times, 29 November.

Cai, Dingjian. 2006. "Bei wudu yu hulue de Xinjiapo jingyan" (The Singaporean experience being misinterpreted and neglected), Dangshi zongheng 4, 37-39.

Cham, Tao Soon. 2014. The Making of NTU: My History. Singapore: Straits Times Press.

Chu, Yun-han, Min-hua Huang and Jie Lu. 2015. "Enter the dragon: how East Asians view a rising China." Global Asia 10(3), 112-120.

Duan, Yanqing, Wanyan Nie and Elayne Coakes. 2010. "Identifying key factors affecting transnational knowledge transfer." Information and Management 47, 356-363.

Fang, Ning. 2016. "Xinjiapo moshi de tezhi he qishi" (Characteristics and lessons of the "Singapore model"), Beijing Daily, 28 March.

Fukuyama, Francis. 1992. "Asia's soft-authoritarian alternative.” New Perspectives Quarterly 9(2), 60-61.

Fukuyama, Francis. 2015. "Exporting the Chinese model," Straits Times, 30 December.

Gao, Junmei, and Wei Liu. 2017. "Zhongguo xiandaihua jincheng zhong xuexi Xinjiapo moshi de lishihuigu yu xianshitansuo" (A review and exploration of China's learning from the "Singapore model" in its industrialization). Changchun keji daxue xuebao 30(2), 28-34.

Ho, Benjamin. 2015. "Learning from Lee: lessons in governance for the middle kingdom from the little red dot." East Asia 32(3), 1-24.

Horesh, Niv, and Jonathan Paris. 2017. "Singapore's success continues to inspire China," The National Interest, 19 March.

$\mathrm{Hu}$, Jiaheng. 2011. "Zhonggong chubei ganbu tanmi: duo bei weiyi zhaoshang yu weiwen zhongren" (Demystify CCP's reserve cadres, generally being appointed to maintain stability or promote investment), Fenghuang zhoukan, 7 December.

Jacques, Martin. 2010. When China Rules the World. London: The Penguin Press.

Ji, Shuoming. 2013. "Xinjiapo peixun yazhou guanyuan zuixin qushi" (The latest trends of Singapore's training of Asian cadres), Yazhou zhoukan, 23 June.

Ji, Yun. 2013. "Bei Zhongguo yizai wudu de Xinjiapo" (Singapore being misunderstood by Chinese), Lianhe zaobao, 13 March.

Jiang, Zemin. 2006. The Selected Works of Jiang Zemin. Beijing: People's Publishing House.

Kong, Hanbing. 2010. "The transplantation and entrenchment of the Soviet Economic Model in China." In Thomas P. Bernstein and Hua-Yu Li (eds.), China Learns from the Soviet Union, 1949-present. Lanham: Rowman \& Littlefield, 153-166.

Kor, Kian Beng. 2015. "Third Singapore-China joint project to be based in Chongqing," Straits Times, 6 November.

Lee, Charlotte. 2015. Training the Party: Party Adaptation and Elite Training in Reform-era China. Cambridge: Cambridge University Press.

Lee, Kuan Yew. 2014. Li Guangyao guan tianxia (One Man's View of the World). Singapore: Singapore Press Holdings Limited. 
Li, Sipan. 2011. "Zhanzai Zhongguo zhiwai kan Zhongguo, Zhongguo guanyuan Xinjiapo qiuxueji” (Looking at China from the outside: A record of Chinese government officials studying in Singapore), Nanfang dushi bao, 18 May.

Lim, Kean Fan and Niv Horesh. 2016. "The "Singapore Fever" in China: policy mobility and mutation." The China Quarterly 228, 992-1017.

Liu, Hong and Els Van Dongen. 2016. "China's diaspora policies as a new mode of transnational governance." Journal of Contemporary China 25(102), 805-821.

Ma, Yufeng. 2004. Ganshou xinjiapo: yige Zhongguoren de guancha yu sikao (Feeling Singapore: A Chinese's Observation and Reflection). Singapore: Candid Creation.

Ortmann, Stephan. 2012. "The "Beijing consensus" and the "Singapore model": unmasking the myth of an alternative authoritarian state-capitalist model." Journal of Chinese Economic and Business Studies 10(4), 337-359.

Ortmann, Stephan, and Mark R. Thompson. 2014. "China's obsession with Singapore: learning authoritarian modernity." The Pacific Review 27(3), 433-455.

Pan, Wei. 2010. Dangdai Zhonghua tizhi: Zhongguo moshi de jingji, zhengzhi, shehui jiexi (The China Model: An Economic, Political, and Social Analysis of the Chinese Institution). Hong Kong: Joint Publishing.

Pan, Xinghua. 2005. "Nanda shizhangban chengwei xinzhong youyi xiangzheng" (The "Mayors' Class" of NTU symbolized the Sino-Singapore friendship), Lianhe zaobao, 1 October.

Pieke, Frank N. 2009. The Good Communist: Elite Training and State Building in Today's China. Cambridge: Cambridge University Press.

Quah, Jon S.T. 1998. "Singapore's model of development: is it transferable." In Henry S. Rowen (ed.), Behind East Asian Growth: The Political and Social Foundations of Prosperity. London: Routledge, 105-125.

Rajah, Jothie. 2012. Authoritarian Rule of Law. Cambridge: Cambridge University Press.

Ramo, Joshua Cooper. 2004. The Beijing Consensus. London: Foreign Policy Centre.

Roy, Denny. 1994. "Singapore, China, and the 'Soft Authoritarian' challenge." Asian Survey 34(3), 231-242.

Shambaugh, David. 2008. China's Communist Party: Atrophy and Adaptation. Washington, D.C.: Woodrow Wilson Center Press.

Shambaugh, David. 2008. "Training China's political elite: the Party School system." The China Quarterly 196, 827-844.

Sonoda, Shigeto. 2014. "Can Singapore model be a model for China? Some insights from the data analysis of the AsiaBarometer 2006." In Xiangqun Chang (ed.), Society Building: A China Model of Social Development. Newcastle: Cambridge Scholars Publishing, 81-90.

Sun, Jiaming, and Scott Lancaster. 2013. "Chinese global connections: from institutions to individuals." In Jiaming Sun and Scott Lancaster (eds.), Chinese Globalization: A Profile of Peoplebased Global Connections in China. New York: Routledge, 77-109.

Sun, Jingfeng. 2002. "Zhongguo xueshujie dui xinjiapo yanjiu shuoguo leilei" (Chinese academia published a great deal of work on Singapore). Dongnanya zongheng 7, 43-44.

Tang, Shiping, and Jie Zhang. 2006. "Zhongguo dongnanya yanjiu xianzhuang: zhiduhua chanshi" (The status of Southeast Asian Studies in China: an institutional illustration). Dangdai yatai 4, 3-12.

Tang, Shiping. 2016. "Zhongguo: yige busuan tai chenggong de fazhanxing guojia" (China: a not very successful developmental nation). FT zhongwenwang, 1 September.

Tsai, Wen-Hsuan, and Nicola Dean. 2013. "The CCP's learning system: thought unification and regime adaptation." The China Journal 69, 87-107.

Tsai, Wen-Hsuan, and Chien-Wen Kou. 2015. "The Party's disciples: CCP Reserve Cadres and the perpetuation of a resilient authoritarian regime." The China Quarterly 221, 1-20.

Tugendhat, Henry, and Dawit Alemu. 2016. "Chinese agricultural training courses for African officials: between power and partnerships." World Development $81,71-81$. 
Vogel, Ezra F. 2012. Deng Xiaoping shidai (Deng Xiaoping and the Transformation of China). Hong Kong: The Chinese University Press.

Wang, Hui. 2011. China's New Order: Society, Politics, and Economy in Transition. Cambridge, MA: Harvard University Press.

Wang, Zhenping. 2008. Zhongguo guanyuan zai xinjiapo: nanyang ligong daxue shizhangban peixun jishi (Chinese Officials in Singapore: A Record of Studying at the "Mayor's Class" in NTU). Shijiazhuang: Huashan Literature \& Art Publishing House.

Wibowo, Ignatius, and Liang Fook Lye. 2006. "China's Central Party School: a unique institution adapting to changes." In Kjeld Erik Brødsgaard and Zheng Yongnian (eds.), The Chinese Communist Party in Reform. London: Routledge, 139-156.

Xi, Jinping. 2014. The Governance of China. Beijing: Foreign Language Press.

Xi, Jinping. 2015. "Accelerating the establishment of Socialist rule of law in China." Qiushi 7(1), $3-15$.

Xia Ke Dao. 2016. "Nanhai shui taishen, xinjiapo ni jiu buyao xia jiaohe le" (The issue of South China Sea is so complicated that Singapore should not be overly involved in), Global Times, 29 September.

Xiao, Gongqin. 2014. "Xinjiapo jingyan dui xili xinzheng de qishi” (Singapore's experience providing inspirations for Xi and Li administration). Tongzhou gongjin 4, 4-9.

Xiao, Shan. 2015. "Wangluo caice xi fensituan xuexi xiaozu shuming xinren Mingze keneng shi Xi Jinping de nüer Xi Mingze" (Netizens guess the newcomer named "Mingze" of the Xi Jinping Study Group is the daughter of Xi Jinping, Xi Mingze), Radio France International, 29 March.

Xue, Yong. 2013. "Zhongguoren de Xinjiapo qingjie" (Chinese's complex of Singapore), Lianhe zaobao, 15 March.

Zhang, Gangzhao. 2013. "Xi Jinping, geerbaqiaofu yu xinjiapo moshi” (Xi Jinping, Gorbachev, and the "Singapore model"), Lianhe zaobao, 11 March.

Zhao, Suisheng. 2017. "Whither the China model: revisiting the debate." Journal of Contemporary China 26(103), 1-17. 